\title{
Dokumentation af undervisningskompe- tencer - om brugen af portfolio i og uden for adjunktuddannelserne
}

\author{
Frederik Voetmann Christiansen, lektor, ph.d. (scient.), Social and Clinical Pharmacy og \\ Institut for Naturfagenes Didaktik, Københavns Universitet.
}

Rie Troelsen, ph.d. (scient.), leder, SDU Universitetspaedagogik, Syddansk Universitet.

\section{Faglig artikel (bedømt af redaktionen)}

Undervisningsportfolioen er $i$ dag et af de mest anvendte formater $i$ universitetsverdenen til at dokumentere undervisningskompetencer. Men hvad er undervisningsportfolioen for en størrelse, og hvordan bliver den brugt som dokumentationsredskab? Vi vil i denne artikel beskrive, hvordan undervisningsportfolioformatet er kommet ind i adjunktuddannelserne, og hvordan det anvendes i dem (baseret på to konkrete eksempler). Endelig vil vi beskrive nye tiltag i relation til anvendelsen af undervisningsportfolio både i og uden for adjunktuddannelserne.

\section{Undervisningsportfolio i adjunktuddannelserne - før og nu}

Adjunktuddannelsen i Danmark blev lovfæstet i forbindelse med indførelsen af stillingscirkulæret i 1994 og har derfor nu været en integreret del af karriereforløbet på universiteterne i mere end 20 år. Omstillingen skete ikke fra den ene dag til den anden, og adjunktuddannelserne har udviklet sig undervejs i takt med universiteternes udvikling, tilkomsten af nye undervisnings- og evalueringsformer og den politiske styring af universiteterne. I 1997 - tre år efter cirkulærets ikrafttræden - udarbejdede rektorkollegiet en rapport om adjunktuddannelse ved universiteterne, hvor de igangværende forløb blev kortlagt, og hvor der blev opstillet retningslinjer for adjunktuddannelsernes nærmere struktur og indhold (Rektorkollegiet, 1997). Rektorkollegiets rapport mundede ud i et sæt fælles anbefalinger for adjunktuddannelsen. Det anbefaledes, at omfanget skulle være ca. 250 timer, og at der, ud over den lovpligtige supervision og udtalelse, skulle indgå "pædagogiske kurser, seminarer, workshops o.lign." (Rektorkollegiet, 1997, s. 2).

I 2004 blev der udarbejdet en rapport om "Pædagogisk uddannelse af adjunkter" (Kruse, Nielsen \& Troelsen, 2004). Målet med rapporten var at analysere "hvilke kompetencer, ud over de fagligt videnskabelige, der betragtes som centrale for universitetsundervisere i dag, og hvordan universiteterne fremmer udviklingen af sådanne kompetencer gennem uddannelsen af deres adjunkter" (Kruse, Nielsen \& Troelsen, 2004). Rapporten indeholdt en analyse af de eksisterende adjunktprogrammers målsætninger og indhold ved de teknisk-naturvidenskabelige uddannel- 
ser, og der blev gennemført en spørgeskemaanalyse og fokusgruppeinterviews med deltagere. Rapporten fremkom endelig med en række anbefalinger til fortsat udvikling af kurserne.

Den mest iøjnefaldende forskel mellem de adjunktuddannelser, der portrætteres i rapporten fra 2004, og de adjunktuddannelser, der findes ved universiteterne i dag, vedrører brugen of undervisningsportfolio til dokumentation af undervisningserfaring og -kompetence. Selvom der er store forskelle på, hvordan der konkret arbejdes med undervisningsportfolio, så indgår deltagernes arbejde med udvikling af en undervisningsportfolio i dag i samtlige adjunktuddannelser (KU, SDU, AU, AAU, ITU, CBS, DTU og RUC) som en integreret del af uddannelsen. Vi vil derfor i denne artikel beskrive, hvad en undervisningsportfolio er, hvordan undervisningsportfolioformatet er kommet ind i adjunktuddannelserne, og hvordan undervisningsportfolio anvendes i dem (baseret på to konkrete eksempler). Vi vil også beskrive nye udviklinger af formater for undervisningsportfolio i og uden for adjunktuddannelserne.

\section{Portfolio som læringsredskab og redskab til dokumentation af undervisnings- kompetencer}

Overordnet set er der to funktioner af en undervisningsportfolio. For det første er den tænkt som et arbejdsredskab eller instrument til løbende refleksion over udvikling og læring. For det andet udgør undervisningsportfolioen en genstand for bedømmelse. Der skelnes ofte mellem en procesportfolio og en præsentationsportfolio, hvor den sidstnævnte er et selektivt og bearbejdet udsnit af den første med henblik på bedømmelse i en bestemt situation - for eksempel ansættelse eller forfremmelse (se fx Krogh, 2007). Idéen med procesportfolioen er, at underviseren løbende og generelt beskriver og reflekterer over udviklingen af egen undervisning, og forestillingen er, at portfolioen bliver et dynamisk produkt, der i sit indhold udvikler sig over tid. På den måde bliver procesportfolioen et element i 'livslang læring' i takt med, at underviseren udvikler sig over tid.

En portfolios indhold er altså afhængig af, hvem modtageren af portfolioen er, men som Smith og Tillema (2003) fremhæver, har portfolioen også forskellig karakter afhængig af incitamentet bag udformningen. Således skelner Smith og Tillema mellem fire forskellige former for undervisningsportfolio alt efter, om målet med udarbejdelsen er læring eller certificering (på den ene side), og om arbejdet er frivilligt eller påkrævet fra institutionens side, se figur 1 . 


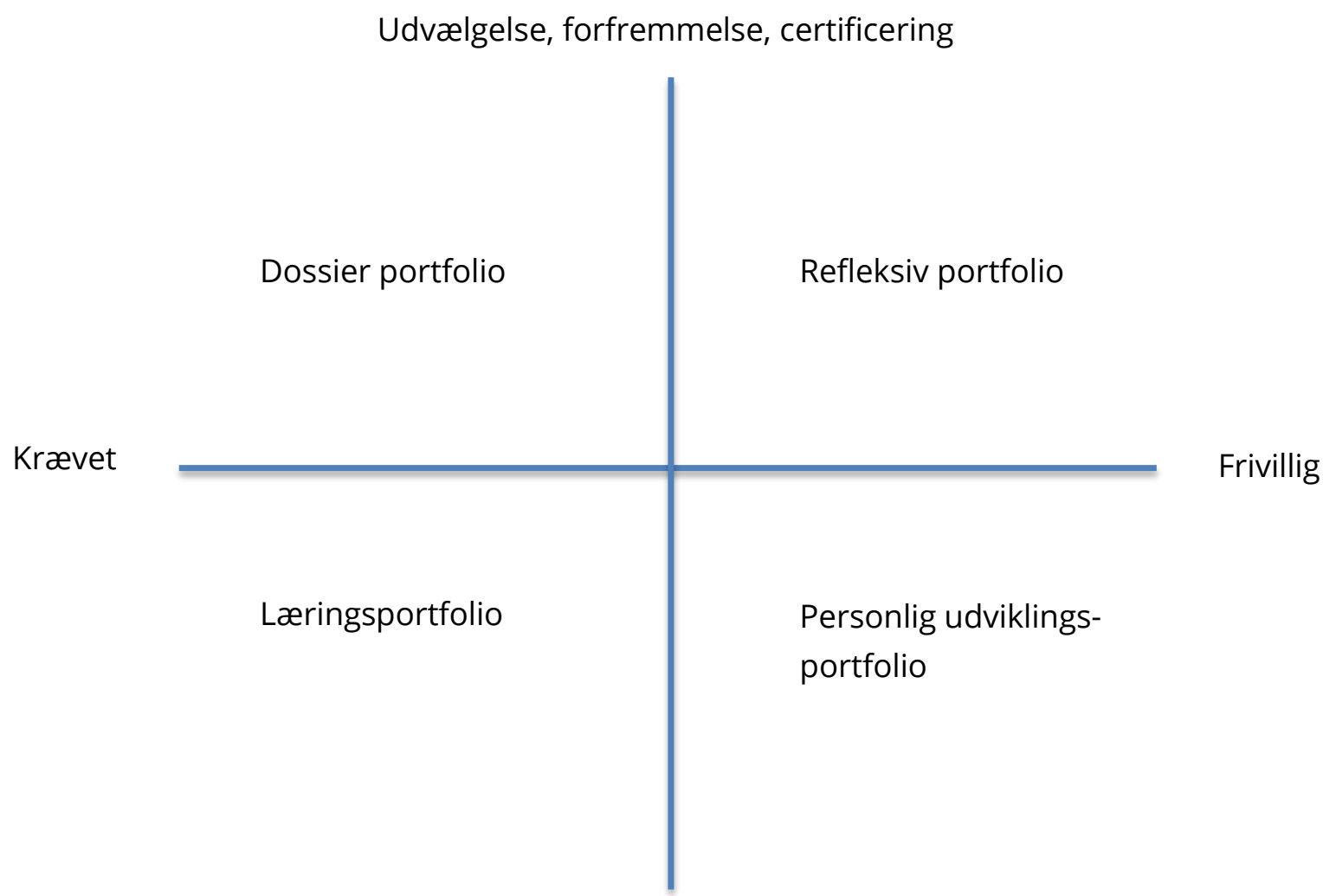

Læring, personlig udvikling

Figur 1: Fire typer portfolio. Portfolioen i adjunktuddannelserne kan betragtes som en laeringsportfolio, mens portfolioen der medsendes en ansøgning kan betragtes som en dossier portfolio (fra Smith \& Tillema, 2003).

Adjunktuddannelsen er et læringsforløb, hvori der indgår et krav om, at der i forløbet skal udarbejdes en undervisningsportfolio svarende til det, der benævnes 'læringsportfolio' i figur 1, hvorimod en portfolio udarbejdet med henblik på ansættelse benævnes en 'dossierportfolio'. Pointen er, at intention, formål, målgruppe og vurderingskriterier er afgørende for udarbejdelsen af portfolioer. Den undervisningsportfolio, der udarbejdes i relation til adjunktuddannelsen, og som lægges til grund for bedømmelsen i adjunktuddannelsen, er dermed ikke - eller i hvert fald ikke nødvendigvis - identisk med den portfolio, der skal afleveres ved en evt. stillingsansøgning. Portfolioens brug - herunder ikke mindst bedømmelseskonteksten - er afgørende. Det er ikke givet, at portfolioen i adjunktuddannelserne lægger vægt på de samme elementer, som bedømmere i et ansættelsesudvalg lægger til grund. Svaret på spørgsmålet "Hvad er en undervisningsportfolio?" kræver således først og fremmest klarhed over, hvad den skal bruges til, og efter hvilke kriterier, den skal bedømmes. I det følgende vil vi træde et skridt tilbage og beskrive, hvordan portfolioformatet er blevet introduceret i både adjunktuddannelserne og ved ansættelser som et redskab til at dokumentere undervisningskompetencer. 


\section{Bedømmelse af undervisningskompetencer - $\mathrm{i}$ adjunktuddannelser og ved an- sættelse}

I stillingscirkulæret, der trådte i kraft i år 2000, blev kravene til ansattes undervisningskompetencer opprioriteret kraftigt i forhold til kvalifikationskravene til både lektorater og professorater (se Christiansen, 2016). Som noget nyt blev det i notatet til stillingsstrukturen beskrevet, at ansøgeren til et lektorat skulle fremlægge "dokumentation for sine undervisningsmæssige kvalifikationer eller anden form for materiale, som kan danne grundlag for en vurdering af ansøgerens undervisningsmæssige/pædagogiske niveau. For adjunkter, der søger lektoransættelse, forudsættes derudover altid vedlagt en vurdering af de undervisningsmæssige kvalifikationer fra adjunktperioden" (Stillingsstruktur, 2000, s. 32). Formuleringen afspejlede et ønske om at opprioritere undervisningskompetencerne i ansættelsen af lektorer. Hvad enten ansøgeren havde fulgt adjunktuddannelsen eller ej, forudsattes altså vedlagt en eller anden form for dokumentation for undervisningskompetencer, men formuleringen var ikke specifik med hensyn til karakteren af denne dokumentation. Ved vedtagelsen af cirkulæret blev dette også rejst som en kritik. I en artikel i Information d. 7/3 2000 udtrykte Danske Studerendes Fællesråds daværende uddannelsespolitiske talsmand Susanne Olling sympati, men også skepsis, over for, om ambitionen om at styrke undervisningen ad denne vej ville lykkes:

"Jeg tror, det er lidt naivt at forestille sig, at man kan aendre traditionen for, at forskning vaegtes højst. Det handler jo ikke kun om prestige blandt kollegerne på de enkelte institutioner, men også forholdet til udenlandske kolleger" (Thorup, 2000, s. 4).

Der blev i artiklen peget på, at forskningskvalifikationer er nemme at måle på gennem publikationer i internationale tidsskrifter, mens det er langt vanskeligere at måle undervisningskvalifikationer. Susanne Olling uddyber:

"Det er et stort arbejde at få fastlagt kriterier, man kan bedømme undervisningen på. Man kan frygte, at der bare bliver målt på beståede eksaminer og andre lignende kvantitative faktorer" (Thorup, 2000, s. 4).

Selvom kravet til dokumentation af undervisningskompetencer gennem medsendt materiale blev fjernet i det efterfølgende cirkulære fra 2004, tog universiteterne opgaven på sig. I adjunktuddannelserne var der flere steder indført undervisningsportfolio ( $f x$ nogle adjunktforløb ved Aalborg og Københavns universiteter). Fra 1. april 2005 indførte Aarhus Universitet som det første et generelt krav ved ansøgning om ansættelse i videnskabelige stillinger om, at der skulle medsendes en undervisningsportfolio (AU, 2004). Interessant nok var beslutningen herom ikke begrundet i de danske erfaringer med anvendelse af portfolio i adjunktuddannelser men truffet især under indtryk af erfaringer og beskrivelser fra USA og Norge (ifølge Torben K. Jensen, pers. komm, jf. fx Seldin, 1997). I de følgende år blev der indført lignende 
krav til nogle eller alle videnskabelige stillinger ved SDU, AAU, CBS, DTU og KU. I takt med det stigende antal erfaringer med brug af undervisningsportfolio i adjunktuddannelserne, og under indtryk af Aarhus Universitets beslutning, begyndte universiteterne altså at stille krav til dokumentation af undervisningskompetencer ved ansættelser gennem undervisningsportfolioer. Der har således ikke været en fælles national beslutning/anbefaling om at stille krav til undervisningsportfolio ved ansættelser, eller for den sags skyld om, at undervisningsportfolier skal indgå i adjunktuddannelserne. Ikke desto mindre er universiteterne drypvis nået frem til en konsensus om, at undervisningsportfolio er modellen, der anvendes i forbindelse med ansættelser i videnskabelige stillinger, og at arbejdet med undervisningsportfolio kan og bør understøttes i adjunktuddannelserne. Der har været en løbende og gensidig påvirkning mellem den universitetspolitiske ambition om at styrke undervisningens status ved ansættelser og brugen af undervisningsportfolio i adjunktuddannelserne. I det følgende vil vi i to cases beskrive, hvordan undervisningsportfolio indgår i hhv. adjunktuddannelsen og ved ansættelser. Vi vil også beskrive, hvordan der er blevet arbejdet med at skabe sammenhæng mellem bedømmelserne i de to situationer på to forskellige måder.

\section{Undervisningsportfolio ved Københavns Universitet}

I 2011 indførte Københavns Universitet fælles retningslinjer for de adjunktuddannelser, der er ved institutionen (justeret i 2014) (KU, 2014). På samme tidspunkt indførtes fælles retningsliner for undervisningsportfolio ved ansættelse i videnskabelige stillinger (KU, 2011). I disse retningslinjer fremgår det, at der som led i adjunktuddannelsen skal udarbejdes en undervisningsportfolio, for at adjunkten derved får "erfaring med undervisningsportfolio som metode til at beskrive, analysere og præsentere pædagogiske problemstillinger". Der var ikke tale om en nyskabelse, da der i de eksisterende adjunktuddannelser ved de fleste fakulteter gennem en årrække havde været stillet krav til udarbejdelse af undervisningsportfolio som led i uddannelsen.

Hvad angår funktionen af portfolioen, så fremgår det af retningslinjerne for adjunktuddannelse, at der ved afslutningen af adjunktforløbet skal laves en skriftlig vurdering af adjunktens undervisningsmæssige kvalifikationer af den pædagogiske og den faglige vejleder, og at undervisningsportfolioen skal indgå i vurderingen af disse. Portfolioen i adjunktuddannelsen er dermed tænkt som et element i bedømmelsesgrundlaget, sammen med (bl.a.) supervisionen. Konkret vil undervisningsportfolioens indhold derfor ofte være en forhandling mellem deltager og de superviserende vejledere: Hvad har vejlederne behov for at få uddybet eller dokumenteret som supplement til den supervision, der har fundet sted, for at de kan skrive en god og dækkende udtalelse til adjunkten? Mens portfolioen og supervisionen således indgår som (en del af) grundlaget for den endelige udtalelse, er der ikke i de fælles retnings- 
linjer fastlagt, hvilke specifikke vurderingskriterier, der lægges til grund for bedømmelsen. Dette overlades til de enkelte udbydere. For de enkelte adjunktuddannelser (ved SCIENCE/SUND, HUM og SAMF) er der udarbejdet vejledninger til bedømmerne, som specificerer, hvad der skal lægges vægt på i bedømmelsen. I grove træk betones evne til at planlægge, gennemføre og evaluere undervisning i bred forstand.

Undervisningsportfolioen i adjunktuddannelserne på KU i perioden frem til i dag har overvejende knyttet sig til adjunktuddannelsens praktiske del. Koblingen mellem adjunktuddannelsernes teoretiske dele og deltagernes portfolioarbejde har dermed ikke været særlig stærk, selvom der i det teoretiske forløb har været oplæg og workshops omkring portfolioarbejdet, herunder diskussion af kravene til undervisningsportfolio ved ansættelser. Det er erfaringen, at mange deltagere har været usikre på, hvordan portfolioarbejdet konkret har skullet gribes an, og at denne usikkerhed måske også skyldtes uklare signaler fra faglige og pædagogiske vejledere. Mange deltagere har derfor valgt at opbygge en undervisningsportfolio med udgangspunkt i de retningslinjer for portfolio, der gælder for ansættelser (KU, 2011) snarere end dem, der gælder for adjunktuddannelserne. For mange har de mere håndfaste anvisninger, der gjaldt for udarbejdelse og vurdering af portfolio i forbindelse med ansættelse været et bedre udgangspunkt for udarbejdelsen end de mere luftige kriterier, som adjunktuddannelserne har opstillet.

Inden for det sidste års tid er der sket en række udviklinger på KU, som sætter et større fokus på anvendelse af undervisningsportfolio uden for adjunktuddannelsen og ikke blot i ansættelsen. Som led i KUs strategiplan for 2016 er der etableret en række pædagogiske indsatser på KU med henblik på at styrke undervisningens status. Blandt de mest opsigtsvækkende er ambitionen om, at alle undervisere skal have en undervisningsportfolio ved udgangen af 2017, og at undervisningsportfolioen skal anvendes i en række forskellige situationer, fx ved Medarbejder Udviklingssamtaler (MUS), ved ansættelse, i adjunktuddannelse, ved lønforhandlinger, ved optagelse i et (potentielt) Teaching Academy mv. Blandt andet for at understøtte denne bredere anvendelse er der vedtaget en fælles poedagogisk kompetenceprofil for universitetet, der kan fungere som en "kortlægning" af undervisningskvalifikationer og - erfaring, og som kan benyttes i forbindelse med udarbejdelsen af undervisningsportfolio i adjunktuddannelsen såvel som i forbindelse med anvendelsen af undervisningsportfolio uden for adjunktuddannelsen.

Kompetenceprofilen er gengivet i hovedtræk i figur 2 (dog uden de uddybende forklaringer) (KU, 2015). Idéen er, at basis for den undervisningsmæssige kompetence udgøres af det fag- og emnekendskab, som enhver universitetsansat underviser må have, og udmøntes videre i erfaringer og kompetencer inden for 6 forskellige områder eller aspekter af undervisningspraksis. Hver af fanerne har uddybende beskrivelser. 


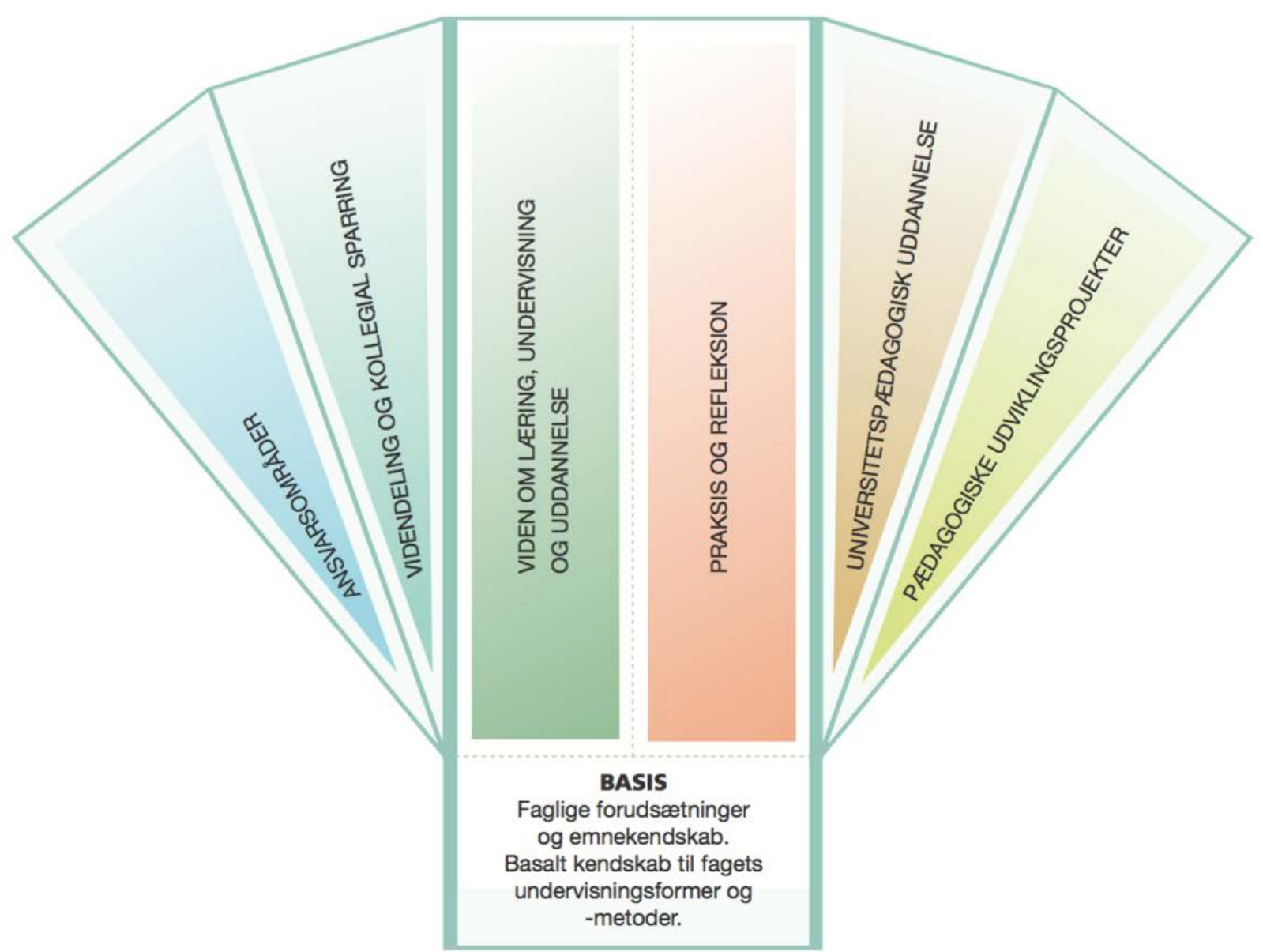

Figur 2: KUs kompetenceprofil for undervisning (KU, 2015).

Kompetenceprofilen er tænkt som en italesættelse af den brede forståelse af undervisning og god undervisningspraksis, der arbejdes med ved KU, og italesætter aspekter af undervisningsbegrebet og værdier, der opfattes som væsentlige i en god pædagogisk praksis ved universitetet. På den måde er profilen inspireret af og ligner i høj grad svenske formater for pedagogisk skicklighet (se Ryegård, Apelgren \& Olsson, 2010) og det britiske "Professional Standards Framework for teaching and supporting learning in higher education" (Higher Education Academy, 2011).

Kompetenceprofilen er ikke tænkt som et vurderingsinstrument i sig selv (og kan næppe bruges som sådant), men den kan bidrage til, at der skabes et fælles sprog om kvalitet i undervisningen. Den kan bidrage til at informere og give kohærens i udarbejdelsen af vurderingskriterier og understøtte den konkrete vurdering i de situationer, hvor undervisningsportfolioer skal bedømmes ( $f x$ ved ansættelse og i forbindelse med adjunktuddannelsen).

Der er for nærværende udviklingsarbejder i gang, hvor de gældende fælles retningslinjer for adjunktuddannelse, de fælles retningslinjer for anvendelse og bedømmelse af portfolio ved ansættelser, og de fælles retningslinjer for MUS vil blive opdateret på en måde, så kompetenceprofilen og undervisningsportfolio inddrages. 


\section{Undervisningsportfolio ved SDU}

Selvom deltagerne på SDUs adjunktuddannelse siden 2010 er blevet præsenteret for portfolio som refleksionsredskab, blev en læringsportfolio først i 2013 indført som en formel del af SDUs adjunktuddannelse (justeret i 2015) (SDU Universitetspædaogik 2015). Samtidig blev en delpolitik for universitetspædagogik og pædagogisk kompetenceudvikling vedtaget som en del af en overordnet kvalitetspolitik på SDU (SDU 2013). I delpolitikken fremhævedes det, at "alle ansatte undervisere har en undervisningsportfolio" (SDU 2013, s. 2). Der har således været en synkron udvikling af portfolio på adjunktuddannelsen og på SDU generelt, hvilket konkret kommer til udtryk ved, at portfolioerne i høj grad spejler sig i hinanden mht. indholdselementer. Da adjunkter efter endt adjunktuddannelsesforløb ikke nødvendigvis får ansættelse på SDU, er læringsportfolioen på adjunktuddannelsen ikke en 1:1 spejling af SDUportfolioen, men er lige så meget tænkt som en træningsbane i overhovedet at beskrive erfaringer, læringssyn og undervisningspraksis i pædagogiske termer.

Læringsportfolioen består af fire elementer: portræt, undervisnings-CV, pædagogisk grundholdning og praksisbeskrivelser:
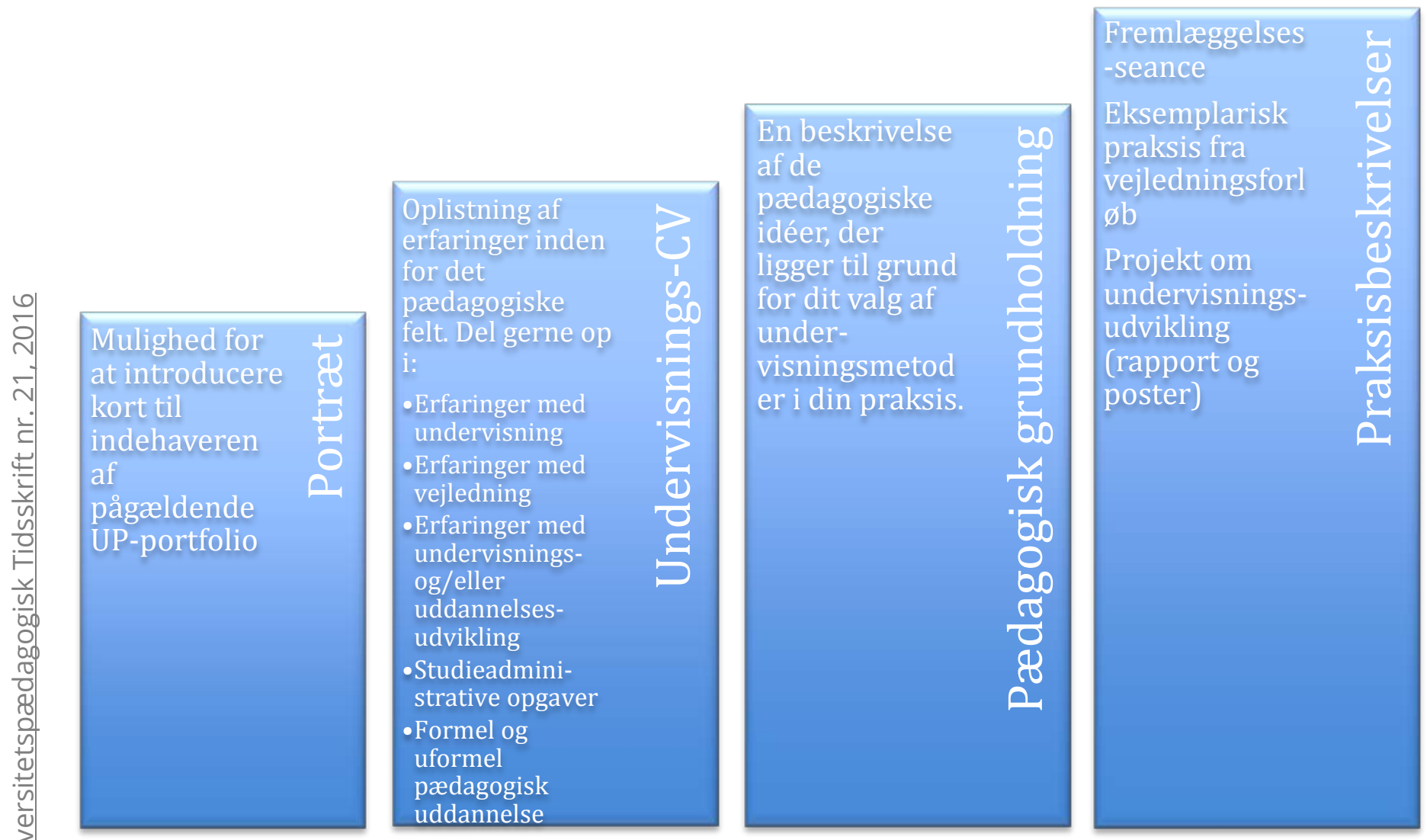

Figur 3: Indholdet i loeringsportfolien ved SDUs adjunktuddannelse.

Portrcettet er en meget kort introduktion, som primært skal sikre, at de personer, som adjunkten vælger at dele sin portfolio med, er klar over hvis portfolio, de er inviteret ind i. Undervisnings-CVet er et udvalg af de erfaringer med undervisning (i bred 
forstand), som adjunkten har haft, og som er relevante for de øvrige refleksioner i portfolioen. Den paedagogiske grundholdning er en kort tekst om adjunktens grundlæggende indstilling til undervisning og læring. Man kan vælge at inddrage og henvise til teoretiske aspekter af pædagogik, som fx læringsteori, men det er ikke nødvendigt. Portfolioen skal desuden indeholde fire eksempler på praksisbeskrivelser: 1) overvejelser i forbindelse med en gruppebaseret undervisningsøvelse - her er der fokus på adjunktens refleksioner over andres undervisning og andres feedback på adjunktens undervisning, 2) overvejelser i forbindelse med en praksis, som har indgået i adjunktens supervision - her er der fokus på adjunktens refleksioner over fx rammefaktorer, uddannelsesmål og underviserrolle, 3) rapport over et projekt om undervisningsudvikling - her er der fokus på refleksioner over et vidensbaseret udviklingsforløb, og endelig 4) en poster over projektet - her er fokus på formidling af undervisningsudvikling.

Adjunktuddannelsen afsluttes med en portfoliosamtale mellem adjunkten og dennes to vejledere (en intern, som typisk har et fagligt fællesskab med adjunkten, og en ekstern, som har en pædagogisk baggrund). Målet med samtalen er, som afslutning på forløbet, at evaluere deltagerens pædagogiske og undervisningsmæssige udvikling. Her træder udviklingspotentialet i læringsportfolioen tydeligt frem, idet samtalen har både et formativt og summativt sigte og danner grundlag for henholdsvis:

1) Deltagerens videre undervisningsmæssige og pædagogiske udvikling.

2) Endelig udtalelse, som udarbejdes af intern vejleder på baggrund af samtalen.

Ved portfoliosamtalen fremlægger adjunkten først, hvilke udviklingsprocesser vedkommende har været igennem i forløbet, og vejlederne supplerer. Herefter fokuseres der på portfolioen i en fælles drøftelse: Hvilket læringsudbytte og pædagogiske kvaliteter er praksisbeskrivelser og pædagogisk grundholdning udtryk for - og hvori består sammenhængen? Som afslutning på portfoliosamtalen bliver de tre parter enige om hvilke formuleringer af adjunktens standpunkt og udviklingsmuligheder som underviser, der skal indgå i den endelige udtalelse.

Udtalelsen består kun af en kort sentens om, at adjunkten på en retvisende måde har beskrevet sin undervisningspraksis og pædagogiske grundholdning i en undervisningsportfolio og 3-4 efterfølgende eksempler fra portfolioen ( $f \times 2$ fra den pædagogiske grundholdning og 2 fra praksisbeskrivelserne), som vejlederen ønsker at fremhæve. Udtalelsen er derfor at opfatte som en introduktion til selve portfolioen som den egentlige dokumentation af adjunktens undervisningskompetencer. 
Som tidligere nævnt, og i lighed med forholdene på KU, er undervisningsportfolioen på SDU indlejret $\mathrm{i}$ et større arbejde med at understøtte kvalitet i undervisningen. SDUs delpolitik for universitetspædagogik og pædagogisk kompetenceudvikling (SDU 2013) angiver indledningsvist, at "undervisere har pædagogisk og didaktisk viden og kompetencer, som løbende udvikles" (ibid., s. 1), hvilket er grundlaget for alt videre arbejde med udvikling af undervisningskvalitet. Hvert andet år gør hver enkelt uddannelse fx status via en uddannelsesberetning, som følger op på, om dens undervisere har de nødvendige kompetencer. Til dette arbejde har SDU udfærdiget en kompetenceprofil, som beskriver de ønskede kompetencer til forskellige opgaver/stillinger:

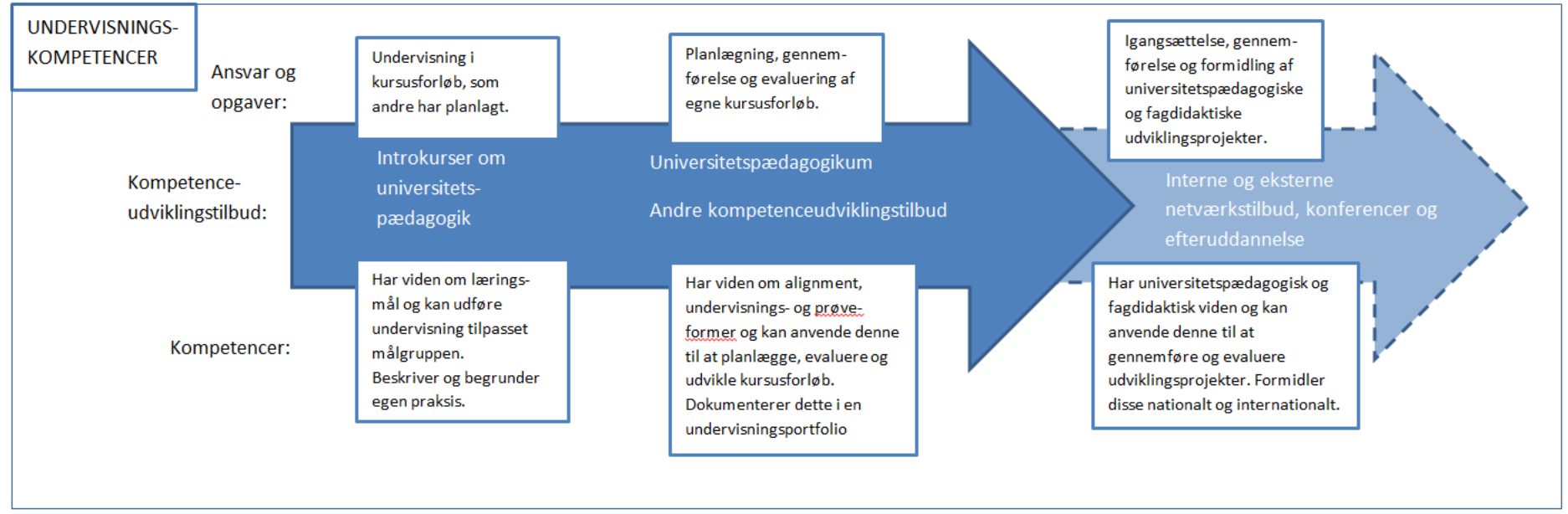

Figur 4: SDUs kompetenceprofil for undervisning (SDU 2015). Universitetspcedagogikum er navnet på SDUs adjunktuddannelse.

Kompetenceprofilen for undervisning på SDU har en pendant i form af en kompetenceprofil for uddannelsesledelse, og begge kompetenceprofiler har uddybende forklaringer om bestanddelene af de enkelte kompetenceniveauer, som ikke er medtaget her.

I delpolitikken for universitetspædagogik og pædagogisk kompetenceudvikling (SDU 2013) hedder det som nævnt, at alle ansatte undervisere har en undervisningsportfolio, og at det er institutlederen, der ved MUS skal følge op på, hvorvidt dette er tilfældet samt vurdere progression og potentiale i portfolioen. I det fortløbende arbejde med at kvalitetssikre og -udvikle undervisningen er det, at undervisere kan dokumentere deres kompetencer, og at institutledere kan evaluere dem, i øvrigt en forudsætning for anerkendelse af undervisning generelt og undervisernes kompetencer i særdeleshed.

Undervisningsportfolio bliver ikke alene anvendt i forbindelse med MUS, men også i ansættelsessituationer som rene dossierportfolier. For begge situationer gælder det imidlertid, at der er vejledninger til rådighed for hhv. ledere og ansættelsesudvalg, men at disse for nærværende er både kortfattede og meget overordnede. Der er $\mathrm{i}$ 
den forbindelse et fremtidigt behov for klarere kriterier og indikatorer for bedømmelse af målopfyldelse og progression i vejledningerne. Vejledningerne skal udvikles og udfoldes både for at sikre validitet og reliabilitet i behandlingen af portfolioer i de enkelte situationer og for at tydeliggøre, at der er tale om forskellige situationer: den første har primært et udviklingssigte og den anden primært et vurderingssigte.

Præcis hvordan læringsportfolioen for de allerede ansatte undervisere skal udformes, er op til det enkelte fakultet på SDU. Men fælles er det, at portfolioerne skal indeholde et CV-element, en reflekteret praksisbeskrivelse og et element om udviklingsønsker/-potentialer. CV-elementet indeholder oversigter over erfaringer relateret til undervisning og uddannelse og skal for de allerede ansattes vedkommende offentliggøres via PURE. De andre dele skal fremsendes til lederen forud for MUSen og kan opbevares i Blackboard (SDUs learning management system), hvor der er skabeloner til rådighed tilpasset hvert fakultet.

\section{Diskussion og perspektivering}

Udarbejdelse af undervisningsportfolioer indgår nu i alle landets større adjunktuddannelser, og alle universiteter stiller krav om medsendelse af undervisningsportfolio ved ansættelser. At det er blevet sådan skyldes ikke mindst, at undervisningsportfolioen politisk opfattes som et godt bud på et svar på en central udfordring for universiteterne: Hvordan sikres det at undervisningsindsatsen bliver tydeliggjort? Selvom der fortsat er væsentlige udfordringer $\mathrm{i}$ anvendelsen af undervisningsportfolio ved ansættelser (især hvad angår reliabiliteten), er det opmuntrende at konstatere, at universiteterne nu kan give et relevant svar på Susanne Ollings bekymring om, hvordan det skal kunne lade sig gøre at lave relevant dokumentation af undervisningskvalifikationer.

Beskrivelserne af anvendelsen af undervisningsportfolio ved SDU og KU peger imidlertid også på, at universiteterne nu også søger svar på - mindst - to andre (politiske) spørgsmål: Hvordan sikrer vi, at de, der skal vurdere undervisningskompetencer, er kompetente til det? - og mere generelt: Hvordan sikres det, at undervisningsindsatsen bliver prioriteret højt i det generelle akademiske arbejde? I svaret på det første spørgsmål ligger der stadig et stykke arbejde foran os - et arbejde med at tydeliggøre kriterierne for dels bedømmelsen af undervisningsportfolio i ansættelses- og mulige forfremmelsessituationer og dels behandlingen af portfolio i MUS-situationer. På KU pågår der et ambitiøst udviklingsarbejde mod at skabe sammenhæng i og på tværs af de fælles retningslinjer, og på SDU får ca. 70 ansatte om året, i kraft af deres position som interne vejledere ved adjunktuddannelsen, erfaringer med at afholde portfoliosamtaler. Retningslinjer og erfaringer vil tilsammen højne kompetencerne hos bedømmerne, men det kommer til at tage tid.

Hvad angår det andet spørgsmål, er det tydeligt, at der ved begge institutioner er ambitioner om øget refleksion, skriftlighed og vidensdeling omkring udvikling af un- 
dervisningspraksis, og at der begge steder ses en bredere anvendelse af undervisningsportfolioen som et middel til at nå dette mål, fx at undervisning skal indgå i MUS. De to modeller for portfolio, der anvendes, er meget forskellige - ved SDU opereres med faste indholdselementer, der skal sikre sammenhængen til praksis, ved $\mathrm{KU}$ er det den pædagogiske kompetenceprofil, der skal understøtte genkendeligheden og sammenhængen i portfolioarbejdet. Forskellighederne til trods er der ikke dog ingen tvivl om, at ambitionen er den samme: At det er nødvendigt at tydeliggøre undervisningsindsatsen gemmen øget skriftlighed og vidensdeling og at anerkende sådanne aktiviteter som en væsentlig del af det akademiske arbejde. Denne bestræbelse ligger i tråd med den internationale bevægelse i retning af styrkelse af "Scholarship of Teaching and Learning" (se fx Shulman, 2000). Om det vil lykkes at få undervisningsportfolioen til at spille denne rolle, vil tiden vise. Undervisningsportfolioen er ikke en magic bullet, og erfaringerne med en sådan bredere anvendelse af undervisningsportfoliobegrebet er sparsomme.

Frederik Voetmann Christiansen er lektor i Naturvidenskabsdidaktik ved Institut for Farmaci ved Det Sundhedsvidenskabelige Fakultet, Københavns Universitet. Hans forskning og undervisning er primaert inden for universitetspaedagogik og uddannelsesforskning, natur- og sundhedsvidenskabelig didaktik, samt natur- og sundhedsvidenskabelig videnskabsteori.

Ph. d. Rie Troelsen er leder af SDU Universitetspaedagogik på SDU, hvor hun arbejder med undervisnings- og uddannelsesudvikling, efteruddannelse og kompetenceudvikling hos universitetsansatte. Forskningsmoessigt har Ries arbejde iscer centreret sig om professionaliseringen af universitetsundervisningen/-underviseren, og mødet mellem studerende og studium. Herudover er hun i de senere år begyndt at interesse sig for samspillet mellem loering og det fysiske loeringsrum.

\section{Litteratur}

AU, (2004). Undervisningsportfolio ved ansaettelse i videnskabelige stillinger. Hentet d. 3. feb. fra http://www.au.dk/?id=244282

Higher Education Academy (2011). The UK Professional Standards Framework for teaching and supporting learning in higher education. The Higher Education Academy, Guild HE, Universities UK.

Krogh, L. (2007). Undervisningsportfolio som redskab i underviserprofessionaliseringsforløb ved universitetet og andre videregående uddannelsesforløb. Aalborg: Institut for Uddannelse, Læring og Filosofi, Aalborg Universitet.

Kruse, S., Nielsen, K. \& Troelsen, R. (2004). Poedagogisk uddannelse af universitetsadjunkter. Analyse af adjunktprogrammerne på de tekniske og 
naturvidenskabelige fakulteter ved højere loereanstalter i Danmark. DCN-Papers no. 20. Aalborg: Dansk Center for Naturvidenskabsdidaktik.

KU (2015). Poedagogisk kompetenceprofil. Hentet 2/2 2016 fra http://uddannelseskvalitet.ku.dk/udviklingsinitiativer/paedagogisk-didaktiskeinitiativer/dokumenter/Viftemodel___KUs_P_dagogiske_Kompetenceprofil.pdf KU (2013). Foelles retningslinjer for universitetspaedagogikum. Oprindelige retningslinjer trådte i kraft i 2011. Hentet 3/2 fra http://uddannelseskvalitet.ku.dk/kvalitetssikring/faellesretningslinjer/paedagogisk_udgangspunkt/universitetspaedagogikum/

KU (2011). Folles retningslinjer for undervisningsportfolio. Hentet 3/2 fra http://uddannelseskvalitet.ku.dk/kvalitetssikring/faellesretningslinjer/paedagogisk_udgangspunkt/undervisningsportfolio/

Rektorkollegiet (1997). Poedagogisk uddannelse af adjunkter på de højere uddannelsesinstitutioner. J.nr. 1996-2066-01, december 1996.

Ryegård, Å., Apelgren, K. \& Olsson, T. (2010). At belägga, bedöma och belöna pedagogisk skicklighet. Uppsala Universitet, Avdelningen för universitetspedagogisk utveckling, PU.

SDU (2013). Delpolitik for universitetspoedagogik og poedagogisk kompetenceudvikling. Hentet 9. nov. 2015 fra http://www.sdu.dk/om_sdu/dokumentation_tal/uddannelseskvalitet/kvalitetsp olitikken.

SDU (2015). Kompetenceprofil for undervisning. Upubliceret.

SDU Universitetspædagogik (2015). Model for universitetspaedagogikum. Hentet d. 9. juni 2016 fra http://www.sdu.dk/om_sdu/institutter_centre/c_unipaedagogik/universitetspae dagogikum/model_ny

Seldin, P. (1997). The Teaching Portfolio: A practical guide to Improved Performance and Promotion/Tenure Decisions. Bolton, MA. Anker Publishing Company

Shulman, L. (2000). From Minsk To Pinsk: Why a scholarship of teaching and learning? Journal of Scholarship of Teaching and Learning, 1(1).

Smith, K. \& Tillema, H. (2003). Clarifying different types of portfolio use. Assessment \& Evaluation in Higher Education, 28(6).

Stillingsstruktur (2000). Stillingsstruktur ved universiteter m.fl. under Forskningsministeriet. Forskningsministeriet, 1.3.1-1, samt Notat om stillingsstruktur for videnskabeligt personale med forskningsopgaver og undervisningsopgaver ved universiteter m.fl. under Forskningsministeriet. Forskningsministeriet 1.3.1-21.

Thorup, M. (2000). Universitetsaftale skal få flere til katederet. Information, 7/3 2000. 